\title{
ANALISIS PENGENDALIAN PERSEDIAAN BAHAN BAKU BUNGA KRANS PADA USAHA BUNGA PLASTIK DENGAN MENGGUNAKAN METODE ECONOMIC ORDER QUANTITY DAN METODE ECONOMIC PRODUCTION QUANTITY
}

\author{
Yulin Tipaka $^{1)}$, Marline Paendong ${ }^{1)}$, Charles Mongi ${ }^{1)}$ \\ ${ }^{1)}$ Program Studi Matematika, Fakultas Matematika dan Ilmu Pengetahuan Alam, \\ Universitas Sam Ratulangi Manado \\ e-mail : yulintipaka@gmail.com; marline.paendong16@gmail.com; charlesmongi@unsrat.ac.id
}

\begin{abstract}
ABSTRAK
Bunga Krans merupakan suatu karangan bunga berbentuk lonjong dan sebagainya untuk ucapan duka cita. Dalam usaha ini tidak sedikit permasalahan tentang meminimumkan biaya dengan mengendalikan prersediaan bahan baku. Tujuan penelitian ini yaitu untuk menentukan jumlah pemesanan ekonomis menggunakan metode Economic Order Quantity (EOQ) dan produksi optimal menggunakan metode Economic Produciton Quantity (EPQ) serta menentukan total persediaan minimum menurut EOQ dan EPQ. Penelitian ini dilakukan pada bulan Februari 2017 hingga April 2017 di perusahaan Kembang Lineke, Girian, Bitung. Dengan variabel yang digunakan yaitu volume kebutuhan bahan baku, volume penyaluran bahan baku, biaya pemesanan bahan baku dan biaya penyimpanan bahan baku. Dari hasil dapat diketahui bahwa pemesanan ekonomis menurut metode EOQ untuk masing-masing jenis bunga K5, K6 dan K10 yaitu 205,88 lusin, 220,09 lusin dan 266,96 lusin dengan biaya optimal semua jenis bunga sebesar Rp. 125.476.400 sedangkan produksi optimal menurut metode EPQ untuk jenis bunga K5, K6 dan K10 masing-masing sebesar 206,16 lusin, 220,4 lusin dan 267,32 lusin dengan biaya optimal untuk semua jenis bunga sebesar Rp. 125.336.630.
\end{abstract}

Kata Kunci: Bunga Krans, Economic Order Quantity (EOQ), Economic Production Quantity (EPQ)

\section{RAW MATERIAL INVENTORY CONTROL ANALYSIS OF FUNERAL WREATH ON PLASTIC FLOWER BUSINESS USING ECONOMIC ORDER QUANTITY METHOD AND ECONOMIC PRODUCTION QUANTITY METHOD}

\begin{abstract}
Funeral wreath is an oval-shaped bouquet or so on used for show greeting or grieving. In this business there are not only a few problems about minimizing costs by controlling raw material inventory. The purpose of this research is to determine the amount of economic order using Economic Order Quantity (EOQ) method and optimum production using Economic Production Quantity (EPQ) method, also to determine the total minimum inventory according to those methods. Where this research was conducted in February 2017 until April 2017 at company Flower Lineke, Girian, Bitung. With variables used are the volume of raw material demand, the volume of raw material distribution, ordering cost and holding cost. From the results it can be seen that economical order according to EOQ method for each type of interest K5, K6 and K10 is 205,88 dozen, 220,09 dozen and 266,96 dozen with optimal cost of all type of interest equal to rp.125,476,400 while the optimum production according to EPQ method for k5, k6, k10, respectively for 206,16 dozen 220,4 dozen and 267,32 dozen with optimal cost for all kinds of interest Rp. 125.336.630.
\end{abstract}

Keywords: Funeral Wreath, Economic Order Quantity (EOQ), Economic Production Quantity (EPQ) 


\section{PENDAHULUAN}

Bunga krans merupakan suatu karangan bunga berbentuk lonjong dan sebagainya untuk ucapan selamat atau duka cita (kbbi, 2012). Namun dalam usaha ini tidak sedikit perusahaan yang memiliki masalah tentang pengadaan persedian bahan baku. Dalam hal ini pengendalian persediaan akan sangat diperlukan dalam melancarkan suatu usaha.

Pengendalian persediaan merupakan pengumpulan atau penyimpanan komoditas yang akan digunakan untuk memenuhi permintaan dari waktu ke waktu. Dimana bentuk dari persediaan yakni berupa bahan mentah, komponen, barang setengah jadi dan lain-lain.

Persediaan berkaitan dengan penyimpanan bahan baku untuk dapat memastikan lancarnya suatu sistem produksi atau usaha bisnis bagi suatu perusahaan/ industri. Dimana persediaan adalah sumber daya atau bahan yang disimpan untuk digunakan selanjutnya pada proses pembuatan suatu produk (Limansyah dan Lasmono, 2011).

Bahan baku merupakan prioritas utama dan sangat vital bagi suatu industri dan proses produksinya. Dimana banyak perusahaan melakukan berbagai metode dalam mengelola persedian bahan baku (Asrori 2010) . Dalam penelitian kali ini bahan baku yang digunakan adalah bunga plastik yang digunakan pada krans bunga.

Metode Economic Order Quantity (EOQ) adalah suatu metode yang digunakan untuk menentukan banyaknya persediaan yang meminimumkan biaya langsung penyimpanan dan biaya kebalikannya (inverse cost) pemesanan persediaan. Metode Economic Production Quantity (EPQ) adalah pengembangan model persediaan di mana pengadaan bahan baku berupa komponen tertentu yang diproduksi secara masal dan dipakai sendiri sebagai sub komponen suatu produk jadi oleh perusahaan.

Metode EOQ dan EPQ telah dipakai pada penelitian-penelitian sebelumnya. Simbar, dkk (2014) menyatakan bahwa pembelian bahan baku Cempaka yang optimal menurut metode EOQ selama periode tahun 2013 Untuk setiap kali pesan lebih besar dari pada yang dilakukan oleh perusahaan. Sibarani, dkk (2013) menyatakan bahwa penggunaan metode EOQ dan EPQ dapat mengurangi biaya persediaan dibandingkan dengan kebijakan perusahaan sendiri. Dari penelitian tersebut dapat dilihat bahwa penggunaan metode EOQ dan EPQ akan sangat membantu perusahaan dalam mengendalikan persediaan bahan baku.

Berdasarkan penjabaran diatas, maka akan dilakukan penelitian untuk menganalisis pengendalian persediaan bahan baku bunga krans pada usaha bunga plastik dengan menggunakan metode EOQ dan EPQ. Perusahaan yang akan diteliti adalah perusahaan kembang Lineke. Kembang Lineke telah berdiri sejak Maret 2010 dengan karyawan berjumlah 5 orang. Dimana bahan baku bunga krans yang digunakan terbagi atas 3 (tiga) jenis bunga yaitu bunga jenis K5 dengan harga $\mathrm{Rp}$. 105.000/lusin, bunga jenis K6 dengan harga Rp.115.000/lusin dan bunga jenis K10 dengan harga Rp. 125.000/lusin. Setiap bunga memiliki perbedaan jumlah. Bunga jenis K5 berjumlah 60 buah/lusin, bunga Jenis K6 berjumlah 72 buah/lusin dan bunga jenis K10 berjumlah 120 buah/lusin. Dengan pemesanan dan penjualan bunga krans pada perusahaan Lineke berjalan normal. Sehingga akan sangat membantu dalam penelitian ini.

\section{Economic Order Quantity (EOQ)}

Metode EOQ adalah salah satu metode dalam manajemen persediaan yang klasik dan sederhana. Perumusan metode EOQ pertama kali ditemukan oleh FW Harris pada tahun 1915, tetapi metode ini sering disebut EOQ Wilson karena metode ini di kembangkan oleh seorang peneliti bernama Wilson pada tahun 1934. Metode ini digunakan untuk menghitung minimalisasi total biaya persediaan berdasarkan persamaan tingkat atau titik equilibrium kurva biaya simpan dan biaya pesan. Dalam model persoalan persediaan ini akan dicari berapa jumlah pemesanan $(\mathrm{Q})$ sehingga total annual cost mencapai minimum.

Metode EOQ adalah suatu metode yang digunakan untuk menentukan banyaknya persediaan yang meminimumkan biaya langsung penyimpanan dan biaya kebalikannya (inverse cost) pemesanan 
persediaan (Fahmi,2012). Secara grafik model persediaan EOQ dapat dilihat pada Gambar 1.

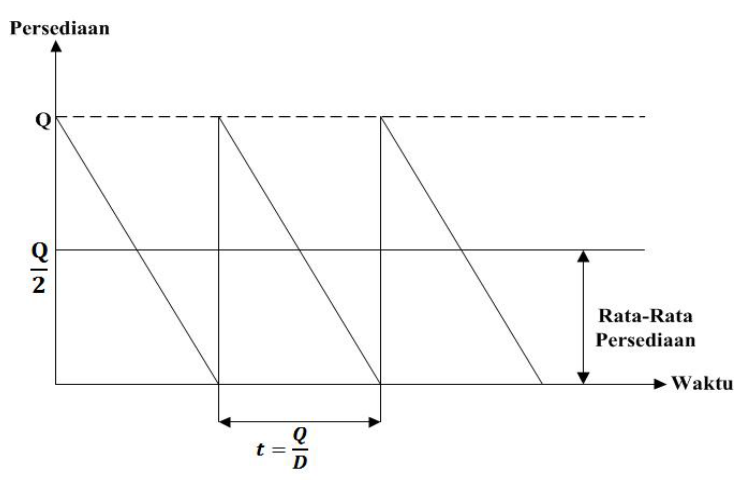

Gambar 1. Grafik EOQ

Gradien garis singgung di titik kritis diperoleh dengan cara menurunkan fungsi yang bersangkutan terhadap variabel keputusan (Taha, 1982).

Notasi-notasi yang digunakan dalam model persediaan barang EOQ adalah: (Taha,2007) $\mathrm{D}=$ Besarnya permintaan barang pertahun. $\mathrm{S}$ = Biaya pemesanan untuk setiap kali pemesanan diajukan.

$\mathrm{H}=$ Biaya penyimpanan perunit barang pertahun.

C = Harga beli barang perunit.

$\mathrm{Q}=$ Jumlah pesanan yang optimum.

$\mathrm{B}=$ Titik pemesanan kembali (reorder point).

$\mathrm{TC}=$ Biaya total persediaan .

Biaya Total Persediaan = Biaya Pembelian+Biaya Pemesanan+Biaya Penyimpanan

Perumusan untuk masing-masing biaya yaitu sebagai berikut:

* Biaya Pembelian

Biaya pembelian=Jumlah barang yang diminta $\times$ Harga perunit barang

$$
=D \times C
$$

* Biaya pemesanan

Biaya pemesanan $=$ Biaya sekali pemesanan $\times$ Frekuensi pemesanan dalam setahun

$$
=\mathrm{S} \times \frac{\mathrm{D}}{\mathrm{Q}}=\frac{\mathrm{S} \times \mathrm{D}}{\mathrm{Q}}
$$

* Biaya penyimpanan

Biaya penyimpanan = Biaya penyimpanan perunit barang $\times$ Rata-rata banyaknya barang yang disimpan

$$
=\mathrm{H} \times \frac{\mathrm{Q}}{2}=\frac{\mathrm{H} \times \mathrm{Q}}{2}
$$

Dengan mensubstitusikan persamaan (2.2), (2.3), dan (2.4) ke dalam persamaan (2.1), maka diperoleh biaya total persediaan untuk model persediaan barang EOQ adalah

$\mathrm{TC}(\mathrm{Q})=\mathrm{D} \times \mathrm{C}+\frac{\mathrm{S} \times \mathrm{D}}{\mathrm{Q}}+\frac{\mathrm{H} \times \mathrm{Q}}{2}$

Selanjutnya untuk mencari nilai $\mathrm{Q}$ sehingga diperoleh biaya total persediaan yang minimum, maka haruslah $\frac{\mathrm{dTC}}{\mathrm{dQ}}=0$. Maka dapat diperoleh

$\frac{\mathrm{dTC}}{\mathrm{dQ}}=0$

$-\frac{\mathrm{S} \times \mathrm{D}}{\mathrm{Q}^{2}}+\frac{\mathrm{H}}{2}=0$

$\frac{\mathrm{S} \times \mathrm{D}}{\mathrm{Q}^{2}}=\frac{\mathrm{H}}{2}$

$\mathrm{Q}^{2}=\frac{2 \times \mathrm{S} \times \mathrm{D}}{\mathrm{H}}$

$Q=\sqrt{\frac{2 \times S \times D}{H}}$

Jadi agar biaya total persediaan menjadi minimum, maka jumlah pesanan yang harus diajukan perusahaan $Q=\sqrt{\frac{2 \times S \times D}{H}}$ adalah unit.

\section{Metode Economic Production Quantity (EPQ)}

Metode EPQ adalah pengembangan model persediaan dimana pengadaan bahan baku berupa komponen tertentu yang diproduksi secara massal dan dipakai sendiri sebagai sub komponen suatu produk jadi oleh perusahaan. Metode EPQ atau tingkat produksi optimal adalah sejumlah produksi tertentu yang dihasilkan dengan meminimumkan total biaya persediaan yang terdiri atas biaya set-up produksi dan biaya penyimpanan (Yamit dan Zulian, 2002). Secara grafik model persediaan EPQ dapat di gambarkan pada Gambar 2. 


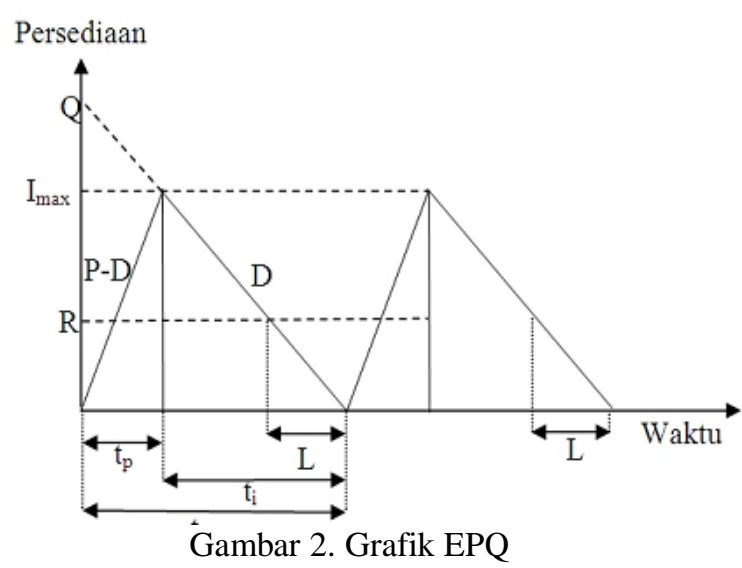

Jumlah produksi yang opitimal untuk metode EPQ secara matematis juga dapat dihitung dengan mendiferensialkan biaya total persediaan (TC) terhadap Q. Dimana Total Cost minimum terjadi jika $\frac{d T C}{Q}=0$ dan $\frac{d^{2} T C}{d Q^{2}}>0$ maka :

$T C=D \times C+\frac{S \times D}{Q}+\frac{H \times Q(p-d)}{2 \times p}$

$\frac{d T C}{d Q}=-\frac{S \times D}{Q^{2}}+\frac{H(p-d)}{2 \times p}=0$

$\frac{S \times D}{Q^{2}}=\frac{H(p-d)}{2 \times p}$

$Q^{2}=\frac{2 \times p \times S \times D}{H(p-d)}$

$Q=\sqrt{\frac{2 \times p \times S \times D}{H(p-d)}}$

Notasi dalam Metode EPQ

$\mathrm{F}=$ Frekuensi pemesanan (kali/satuan waktu)

$\mathrm{L}=$ Waktu yang di perlukan untuk memproduksi kembali ( satuan waktu)

$\mathrm{TC}=$ Biaya total persediaan (rupiah/satuan waktu)

$\mathrm{p}=$ Rata-rata penyaluran (satuan unit/satuan waktu)

$\mathrm{d}=$ Rata-rata penyaluran (satuan unit/satuan waktu)

$\mathrm{t}=$ Jarak waktu antara pesan (satuan waktu)

$t_{p}=$ Waktu selama siklus produksi ( satuan waktu)

\section{METODOLOGI PENELITIAN}

Analisis penelitian telah dilaksanakan kurang lebih tiga bulan. Dimulai dari bulan Februari 2017 Hingga April 2017. Tempat pelaksanaan penelitian di Perusahaan
Kembang "Lineke" di Jln. Utama Girian, Bitung. Analisis data telah di laksanakan di program studi Matematika, Fakultas Matematika dan Ilmu Pengetahuan Alam, Universitas Sam Ratulangi, Manado.

\section{Jenis Pengumpulan Data dan Konsepsi} Pengumpulan Variabel

Variabel yang digunakan dalam penelitian ini adalah :

1. Volume kebutuhan bahan baku(lusin/bulan).

2. Volume penyaluran bahan baku (lusin/bulan).

3. Biaya pemesanan bahan baku (Rp/lusin), adalah biaya yang dikeluarkan sehubungan dengan pemesanan bahan baku, antara lain :
a. Biaya telepon
b. Biaya transportasi
c. Biaya Sopir

4. Biaya penyimpanan (Rp/lusin), adalah biaya yang dikeluarkan sehubungan dengan penyimpana bahan baku, antara lain :
a. Biaya gudang
b. Biaya listrik
c. Upah penjaga gudang

\section{Metode Analisis Data}

Penelitian ini dilakukan dengan beberapa tahapan yakni seperti terlihat pada Gambar 3. Dengan rumus yang digunakan pada penelitian ini terdapat pada Tabel 1 .

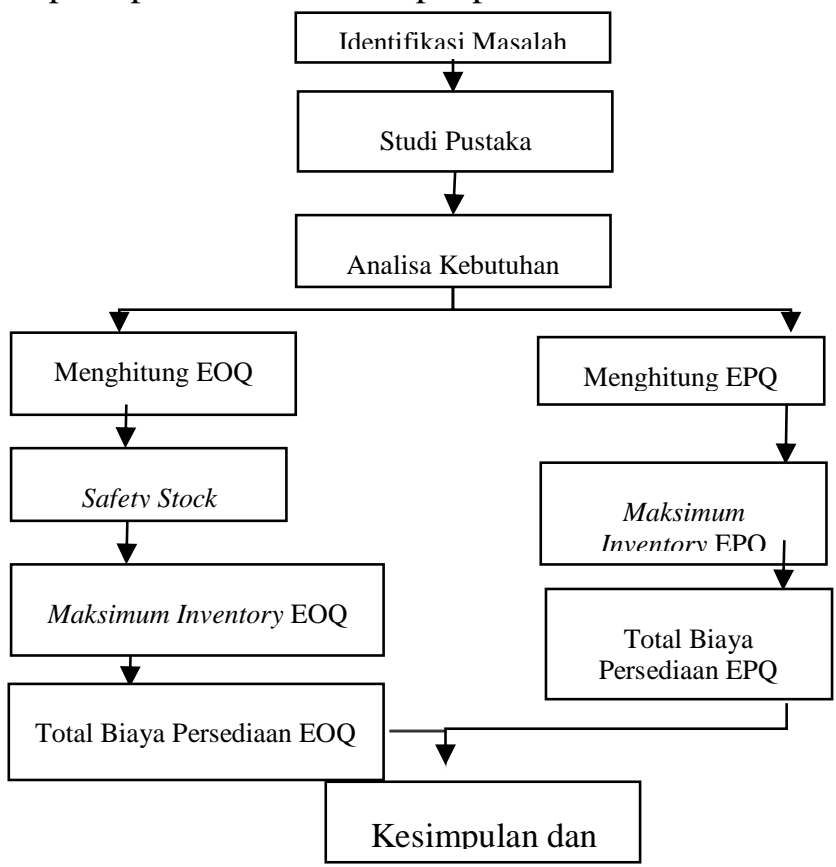

Gambar 3. Bagan Analisis Data 
Tabel 1. Daftar Rumus Yang Digunakan.

\begin{tabular}{|c|c|}
\hline $\begin{array}{l}\text { Menghitung } \\
\text { EOQ }\end{array}$ & $E O Q=\sqrt{\frac{2 D S}{H}}$ \\
\hline Menghitung EPQ & $E P Q=\sqrt{\frac{2 p S_{c} D}{H_{c}(p-d)}}$ \\
\hline Safety stock & $S S=Z \times \sigma$ \\
\hline $\begin{array}{l}\text { Maksimum } \\
\text { inventory EOQ }\end{array}$ & $I_{\max }=S S+E O Q$ \\
\hline $\begin{array}{l}\text { Maksimum } \\
\text { inventory } \mathrm{EPQ}\end{array}$ & $I_{\max }=E P Q\left(1-\frac{d}{p}\right)$ \\
\hline $\begin{array}{l}\text { Total biaya } \\
\text { persediaan EOQ }\end{array}$ & $\begin{array}{l}T C(Q) \\
=\left(\frac{D}{E O Q}\right) S \\
+\left(\frac{E O Q}{2}\right) H\end{array}$ \\
\hline $\begin{array}{l}\text { Total biaya } \\
\text { persediaan EPQ }\end{array}$ & $\begin{array}{l}T C(Q) \\
=(d p) \\
+(E P Q) \cdot H\left(\frac{p-d}{p}\right)\end{array}$ \\
\hline
\end{tabular}

Tabel 2. Kuantitas Pembelian Dan Penyaluran Bunga Plastik Jenis K5 (Rp.105.000/Lusin)

\begin{tabular}{|l|l|l|l|l|l|}
\hline No & Bulan & $\begin{array}{l}\text { Pembe } \\
\text { lian } \\
\text { (Lusin) }\end{array}$ & $\begin{array}{l}\text { Persedi } \\
\text { aan } \\
\text { (Lusin) }\end{array}$ & $\begin{array}{l}\text { Penyal } \\
\text { uran } \\
\text { (Lusin) }\end{array}$ & $\begin{array}{l}\text { Sisa } \\
\text { (Lus } \\
\text { in) }\end{array}$ \\
\hline 1 & Januari & 20 & 20 & 15 & 5 \\
\hline 2 & $\begin{array}{l}\text { Februa } \\
\text { ri }\end{array}$ & 20 & 25 & 23 & 2 \\
\hline 3 & Maret & 25 & 27 & 19 & 8 \\
\hline 4 & April & 20 & 28 & 24 & 4 \\
\hline 5 & Mei & 25 & 29 & 21 & 8 \\
\hline 6 & Juni & 20 & 28 & 26 & 2 \\
\hline 7 & Juli & 25 & 27 & 18 & 9 \\
\hline 8 & $\begin{array}{l}\text { Agustu } \\
\text { s }\end{array}$ & 20 & 29 & 23 & 6 \\
\hline 9 & $\begin{array}{l}\text { Septem } \\
\text { ber }\end{array}$ & 20 & 26 & 24 & 2 \\
\hline 10 & $\begin{array}{l}\text { Oktobe } \\
\text { r }\end{array}$ & 20 & 22 & 21 & 1 \\
\hline 11 & $\begin{array}{l}\text { Novem } \\
\text { ber }\end{array}$ & 30 & 31 & 24 & 7 \\
\hline 12 & $\begin{array}{l}\text { Desem } \\
\text { ber }\end{array}$ & 30 & 37 & 35 & 2 \\
\hline & Total & 275 & 329 & 273 & 56 \\
\hline & $\begin{array}{l}\text { Rata- } \\
\text { rata }\end{array}$ & 22,916 & 27,416 & 22,75 & 4,67 \\
\hline
\end{tabular}

\section{HASIL DAN PEMBAHASAN}

Perusahaan melakukan pembelian bahan baku 2 (dua) kali per 1 (satu) bulan, dengan alasan sebagai persediaan dalam proses produksi. Berikut ini tabel jumlah Pembelian dan penyaluran bahan baku tahun 2016 pada Kembang Lineke.

Tabel 2 menyatakan bahwa di tahun 2016 pembelian bahan baku bunga plastik dengan jenis K5 lebih besar dari pada penyaluran bahan baku bunga plastik dengan jenis K5. Pembelian bahan baku K5 tahun 2016 sebanyak 275 lusin, sedangkan penyaluran bahan baku K5 tahun 2016 sebanyak 273 lusin. Frekuensi pembelian selama tahun 2016 sebanyak 24 kali karena setiap bulan 2 (dua) kali perusahaan membeli bahan baku dengan total pembelian perbulan seperti pada table 2. Untuk pembelian rata-rata bunga plastik Jenis K5 selama tahun 2016 adalah sebesar 22,916 lusin sedangkan penyaluran rata-rata bunga plastik sebanyak 22,75 lusin. Dikarenakan jumlah pembelian lebih besar dari pada jumlah penyaluran mengakibatkan adanya pengeluaran berupa biaya penyimpanan gedung. Berikut histogram dari data pada Tabel 2 .

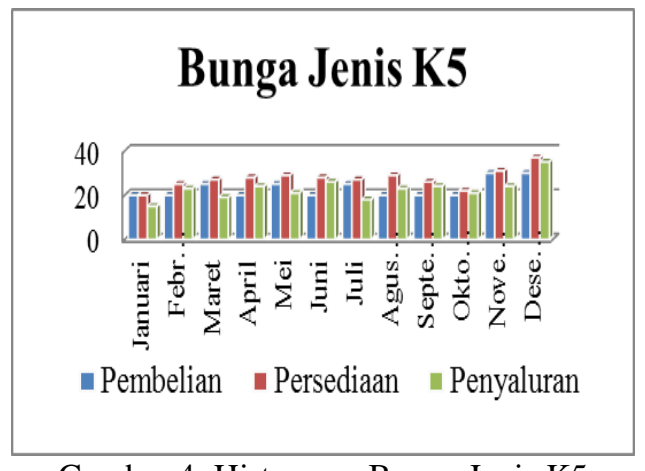

Gambar 4. Histogram Bunga Jenis K5

Gambar 4 menyatakan bahwa pembelian bahan baku bunga plastik dengan jenis K5 terbanyak terdapat pada bulan November dan Desember. Sedangkan penyaluran tertinggi terdapat terdapat pada bulan Desember. 
Tabel 3. Kuantitas Pembelian Dan Penyaluran Bunga Plastik Jenis K6 (Rp.115.000/Lusin)

\begin{tabular}{|l|l|l|l|l|l|}
\hline $\begin{array}{l}\text { N } \\
\text { o }\end{array}$ & Bulan & $\begin{array}{l}\text { Pembeli } \\
\text { an } \\
\text { (Lusin) }\end{array}$ & $\begin{array}{l}\text { Persedia } \\
\text { an } \\
\text { (Lusin) }\end{array}$ & $\begin{array}{l}\text { Penya } \\
\text { luran } \\
\text { (Lusi } \\
\text { n) }\end{array}$ & $\begin{array}{l}\text { Sisa } \\
\text { (Lusin) }\end{array}$ \\
\hline 1 & Januari & 30 & 30 & 20 & 10 \\
\hline 2 & Februari & 25 & 35 & 30 & 5 \\
\hline 3 & Maret & 30 & 35 & 27 & 8 \\
\hline 4 & April & 25 & 33 & 31 & 2 \\
\hline 5 & Mei & 30 & 32 & 28 & 4 \\
\hline 6 & Juni & 25 & 29 & 27 & 2 \\
\hline 7 & Juli & 30 & 32 & 26 & 6 \\
\hline 8 & Agustus & 25 & 31 & 27 & 4 \\
\hline 9 & $\begin{array}{l}\text { Septemb } \\
\text { er }\end{array}$ & 20 & 24 & 21 & 3 \\
\hline 10 & Oktober & 20 & 23 & 19 & 4 \\
\hline 11 & $\begin{array}{l}\text { Novembe } \\
\text { r }\end{array}$ & 25 & 29 & 27 & 2 \\
\hline 12 & $\begin{array}{l}\text { Desembe } \\
\text { r }\end{array}$ & 30 & 32 & 29 & 3 \\
\hline & Total & 315 & 365 & 312 & 53 \\
\hline & Rata-rata & 26,25 & 30,4167 & 26 & 4,4167 \\
\hline
\end{tabular}

Tabel 3 menyatakan bahwa di tahun 2016 pembelian bahan baku bunga plastik dengan jenis K6 lebih besar dari pada penyaluran bahan baku bunga plastik dengan jenis K6. Pembelian bahan baku K6 tahun 2016 sebanyak 315 lusin, sedangkan penyaluran bahan baku K6 tahun 2016 sebanyak 312 lusin. Frekuensi pembelian selama tahun 2016 sebanyak 24 kali karena setiap bulan 2 (dua) kali perusahaan membeli bahan baku dengan total pembelian perbulan seperti pada table 2. Untuk pembelian rata-rata bunga plastik Jenis K6 selama tahun 2016 adalah sebesar 26,25 lusin sedangkan penyaluran rata-rata bunga plastik sebanyak 26 lusin.

Dikarenakan jumlah pembelian lebih besar dari pada jumlah penyaluran mengakibatkan adanya pengeluaran berupa biaya penyimpanan gedung. Berikut histogram dari data pada Tabel 3.

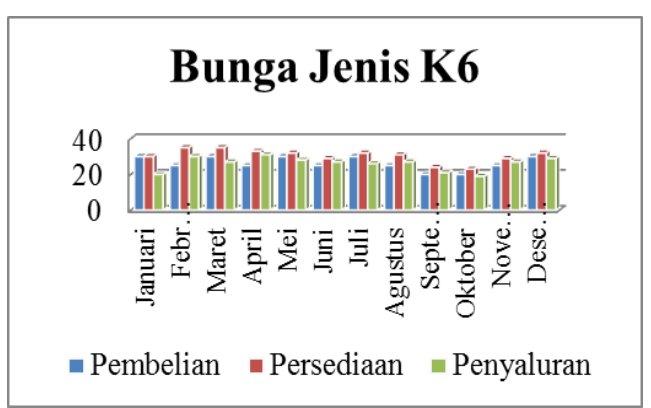

Gambar 5. Histogram Bunga Jenis K6

Gambar 5 menyatakan bahwa pembelian bahan baku bunga plastik dengan jenis K6 terbanyak terdapat pada bulan Januari, Maret, Mei, Juli dan Desember. Sedangkan penyaluran tertinggi terdapat terdapat pada bulan April.

Tabel 4. Kuantitas Pembelian Dan Penyaluran Bunga Plastik Jenis K10 (Rp.125.000/Lusin)

\begin{tabular}{|l|l|l|l|l|l|}
\hline $\begin{array}{l}\text { N } \\
\text { o }\end{array}$ & Bulan & $\begin{array}{l}\text { Pembeli } \\
\text { an } \\
\text { (Lusin) }\end{array}$ & $\begin{array}{l}\text { Persedia } \\
\text { an } \\
\text { (Lusin) }\end{array}$ & $\begin{array}{l}\text { Penyalur } \\
\text { an } \\
\text { (Lusin) }\end{array}$ & $\begin{array}{l}\text { Sisa } \\
\text { (Lusi } \\
\text { n) }\end{array}$ \\
\hline 1 & Januari & 40 & 40 & 35 & 5 \\
\hline 2 & Februari & 40 & 45 & 37 & 8 \\
\hline 3 & Maret & 35 & 43 & 40 & 3 \\
\hline 4 & April & 40 & 43 & 37 & 6 \\
\hline 5 & Mei & 35 & 41 & 39 & 2 \\
\hline 6 & Juni & 40 & 42 & 38 & 4 \\
\hline 7 & Juli & 40 & 44 & 35 & 9 \\
\hline 8 & Agustus & 30 & 39 & 34 & 5 \\
\hline 9 & $\begin{array}{l}\text { Septemb } \\
\text { er }\end{array}$ & 40 & 45 & 39 & 6 \\
\hline 10 & Oktober & 35 & 41 & 34 & 7 \\
\hline 11 & $\begin{array}{l}\text { Novemb } \\
\text { er }\end{array}$ & 40 & 47 & 45 & 2 \\
\hline 12 & $\begin{array}{l}\text { Desemb } \\
\text { er }\end{array}$ & 50 & 52 & 46 & 6 \\
\hline Total & 465 & 522 & 459 & 63 \\
\hline $\begin{array}{l}\text { Rata- } \\
\text { rata }\end{array}$ & 38,75 & 43,5 & 38,25 & 5,25 \\
\hline
\end{tabular}

Dalam Tabel 4 dapat dilihat bahwa di tahun 2016 pembelian bahan baku bunga plastik dengan jenis K10 lebih besar dari pada penyaluran bahan baku bunga plastik dengan jenis K10. Pembelian bahan baku K10 tahun 2016 sebanyak 315 lusin, sedangkan penyaluran bahan baku K10 tahun 2016 sebanyak 312 lusin. Frekuensi pembelian selama tahun 2016 sebanyak 24 kali karena setiap bulan 2 (dua) kali perusahaan membeli bahan baku dengan 
total pembelian perbulan seperti pada table 4. Untuk pembelian rata-rata bunga plastik Jenis K10 selama tahun 2016 adalah sebesar 38,75 lusin sedangkan penyaluran rata-rata bunga plastik sebanyak 38,25 lusin.

Dikarenakan jumlah pembelian lebih besar dari pada jumlah penyaluran mengakibatkan adanya pengeluaran berupa biaya penyimpanan gedung. Berikut histogram dari data pada Tabel 4 .

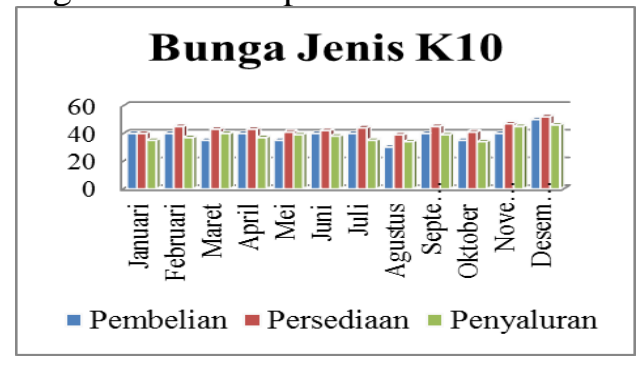

Gambar 6. Histogram Bunga Jenis K10

Gambar 6 menyatakan bahwa pembelian bahan baku bunga plastik dengan jenis K10 terbanyak terdapat pada bulan Desember. Sedangkan penyaluran tertinggi untuk bunga Jenis K10 juga terdapat terdapat pada bulan Desember.

\section{Biaya Pemesanan}

Biaya pemesanan yang dikeluarkan oleh perusahan setiap kali pesan yaitu biaya Pulsa sebesar Rp. 10.000, biaya Bensin sebesar Rp. 150.000 dan gaji Supir yaitu sebesar Rp. 2.000.000 per bulan.

Tabel 5. Biaya Pemesanan Bahan Baku Bunga Plastik Periode Tahun 2016

\begin{tabular}{|l|l|r|}
\hline No & Jenis Biaya & \multicolumn{1}{|c|}{ Rp/Tahun } \\
\hline 1 & Pulsa & 240.000 \\
\hline 2 & Bensin & 3.600 .000 \\
\hline 3 & Supir & 24.000 .000 \\
\hline & Jumlah & 27.840 .000 \\
\hline & Rp/Kali & 1.160 .000 \\
\hline
\end{tabular}

Tabel 5 terlihat bahwa Biaya yang dikeluarkan Kembang Lineke untuk pemesanan masing-masing jenis bunga adalah Rp. 386.667.-

\section{Biaya Penyimpanan}

Biaya Penyimpanan yang di keluarkan oleh perusahaan yaitu berupa biaya listrik, biaya Gudang dan Upah Penjaga Gudang. Yang biayanya dibagi dengan banyaknya bahan baku yang disalurkan.

Tabel 6. Biaya Penyimpanan Bahan Baku Bunga Plastik

\begin{tabular}{|c|l|c|}
\hline No & \multicolumn{1}{|c|}{ Jenis Biaya } & Rp/bulan \\
\hline 1 & Listrik & 200.000 \\
\hline 2 & Gudang & 3.000 .000 \\
\hline 3 & $\begin{array}{l}\text { Upah Penjaga } \\
\text { Gudang }\end{array}$ & 2.000 .000 \\
\hline & Jumlah & 5.200 .000 \\
\hline
\end{tabular}

Tabel 6 menjelaskan banyaknya biaya penyimpanan bahan baku. Pada biaya penyimpanan tidak hanya bunga krans yang disimpan, maka biaya penyimpanan yang digunakan untuk menyimpan bunga krans sebesar $20 \%$ dari seluruh biaya dengan biaya sebesar Rp. 1.040 .000 dengan biaya penyimpana perunit yang harus dikeluarkan adalah sebesar Rp. 996.

\section{Perhitungan Dengan Metode EOQ}

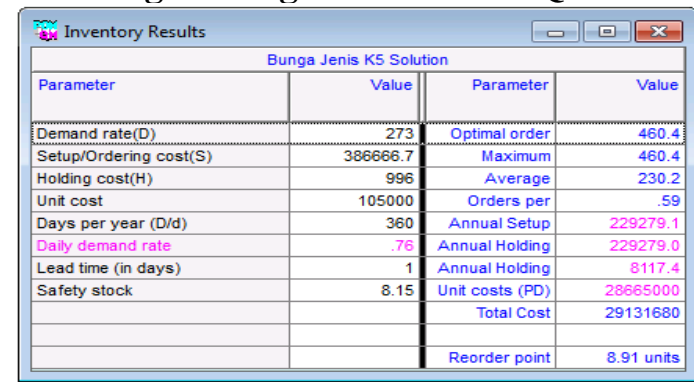

Gambar 7. Economic Order Quantity Bunga Jenis K5

Gambar 7 Menunjukkan kuantitas pemesanan optimal bunga Jenis K5 sebesar 460 lusin, level persediaan maksimal sebesar 460 lusin, rata-rata persediaan 230 lusin, pesanan per periode (Tahun) sebesar 1 kali. Biaya pemesanan tahunan sebesar Rp.229.279, biaya penyimpanan tahunan sebesar Rp.229.279 dan biaya penyimpanan persediaan pengaman tahunan sebesar Rp.8.117. Untuk biaya unit sebesar Rp. 28.665.000 dan Total Biaya sebesar Rp.29.131.680. Dengan pemesanan kembali pada saat persediaan bahan baku digudang sisa 9 lusin. 


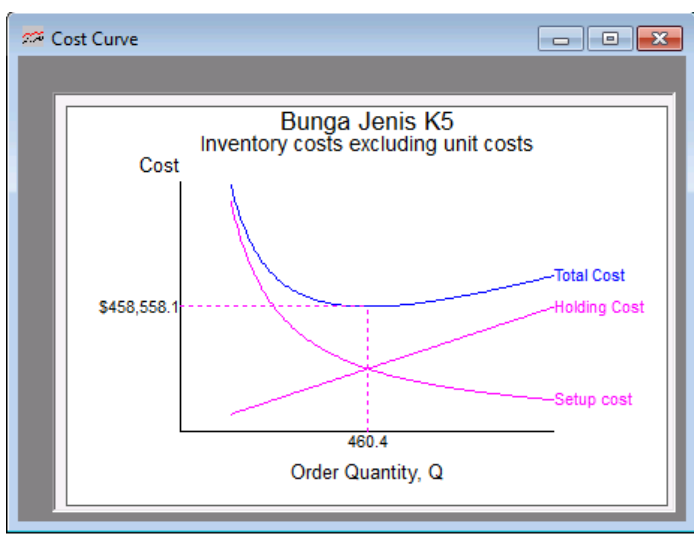

Gambar 8. Kurva Persediaan EOQ Jenis Bunga K5

Gambar 8 Menjelaskan bahwa titik persediaan optimal di dapat apabila biaya minimum sebesar Rp.458.558 dan berada pada tingkat persediaan sebesar 460 lusin.

\begin{tabular}{|c|c|c|c|}
\hline \multicolumn{3}{|l|}{ Wi Inventory Results } & D $-x$ \\
\hline \multicolumn{4}{|c|}{ Bunga Jenis K6 Solution } \\
\hline Parameter & Value & Parameter & Value \\
\hline Demand rate $(\mathrm{D})$ & 312 & Optimal order quantity $\left(Q^{*}\right)$ & 492.19 \\
\hline Setup/Ordering $\operatorname{cost}(\mathrm{S})$ & 386666.7 & Maximum Inventory Level (Imax) & 492.19 \\
\hline Holding cost(H) & 996 & Average inventory & 246.09 \\
\hline Unit cost & 115000 & Orders per period(year) & .63 \\
\hline Days per year (D/d) & 360 & Annual Setup cost & 245109.6 \\
\hline Daily demand rate & .87 & Annual Holding cost & 245109.6 \\
\hline Lead time (in days) & 1 & Annual Holding (safety stock) & 6424.2 \\
\hline \multirow[t]{3}{*}{ Safety stock } & 6.45 & Unit costs $(\mathrm{PD})$ & 35880000 \\
\hline & & Total Cost & 36376640 \\
\hline & & Reorder point & 732 units \\
\hline
\end{tabular}

Gambar 9. Economic Order Quantity Bunga Jenis K6

Gambar 9 Menunjukkan kuantitas pemesanan optimal bunga Jenis K6 sebesar 492 lusin, level persediaan maksimal sebesar 492 lusin, rata-rata persediaan 246 lusin, pesanan per periode (Tahun) sebesar 1 kali. Biaya pemesanan tahunan sebesar Rp.245.109, biaya penyimpanan tahunan sebesar Rp.245.109 dan biaya penyimpanan persediaan pengaman tahunan sebesar Rp.6.424.. Untuk biaya unit sebesar Rp. 35.880.000 dan Total Biaya sebesar Rp.36.376.640. Dengan pemesanan kembali pada saat persediaan bahan baku digudang sisa 7 lusin.

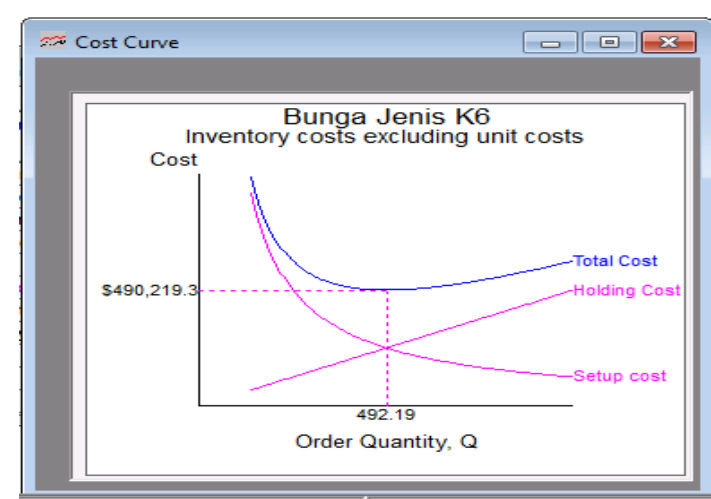

Gambar 10. Kurva Persediaan EOQ Jenis Bunga K6

Gambar 10 Menjelaskan bahwa titik persediaan optimal di dapat apabila biaya minimum sebesar Rp.490.219 dan berada pada tingkat persediaan sebesar 492 lusin.

\begin{tabular}{|c|c|c|c|}
\hline \multicolumn{3}{|l|}{ Inventory Results } & $\square \quad \square$ \\
\hline \multicolumn{4}{|c|}{ Bunga Jenis K10 Solution } \\
\hline Parameter & Value & Parameter & Value \\
\hline Demand rate $(\mathrm{D})$ & 459 & Optimal order quantity $\left(Q^{*}\right)$ & 596.98 \\
\hline Setup/Ordering cost(S) & 386666.7 & Maximum Inventory Level (Imax) & 596.98 \\
\hline Holding $\cos t(\mathrm{H})$ & 996 & Average inventory & 298.49 \\
\hline Unit cost & 125000 & Orders per period(year) & .77 \\
\hline Days per year (D/d) & 360 & Annual Setup cost & 297296.3 \\
\hline Daily demand rate & 1.28 & Annual Holding cost & 297296.2 \\
\hline Lead time (in days) & 1 & Annual Holding (safety stock) & 6464.04 \\
\hline \multirow[t]{4}{*}{ Safety stock } & 6.49 & Unit costs $(P D)$ & 57375000 \\
\hline & & Total Cost & 57976060 \\
\hline & & & \\
\hline & & Reorder point & 7.77 units \\
\hline
\end{tabular}

Gambar 11. Economic Order Quantity Bunga Jenis K10

Gambar 11 Menunjukkan kuantitas pemesanan optimal bunga Jenis K10 sebesar 597 lusin, level persediaan maksimal sebesar 597 lusin, rata-rata persediaan 298 lusin, pesanan per periode (Tahun) sebesar 1 kali. Biaya pemesanan tahunan sebesar Rp.297.296, biaya penyimpanan tahunan sebesar Rp.297.296 dan biaya penyimpanan persediaan pengaman tahunan sebesar Rp.6.464. Untuk biaya unit sebesar $\mathrm{Rp}$. 57.375.000 dan Total Biaya sebesar Rp.57.976.060. Dengan pemesanan kembali pada saat persediaan bahan baku digudang sisa 8 lusin. 


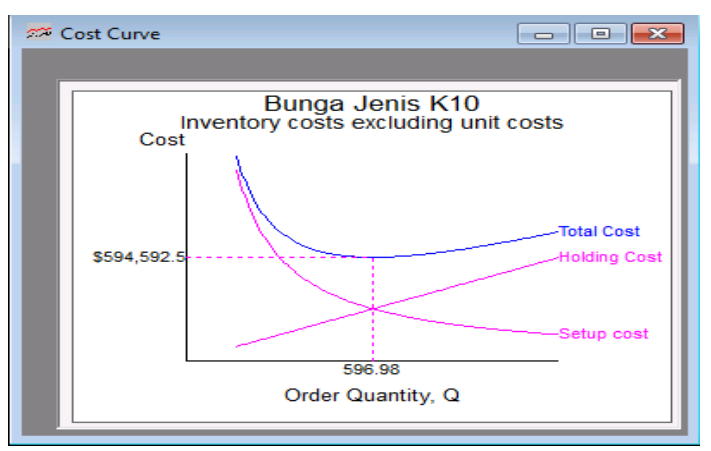

Gambar 12. Kurva Persediaan EOQ Jenis Bunga K10

Gambar 12. Menjelaskan bahwa titik persediaan optimal di dapat apabila biaya minimum sebesar Rp.594.593 dan berada pada tingkat persediaan sebesar 597 lusin.

\section{Perhitungan Dengan Metode EPQ}

\begin{tabular}{|c|c|c|c|}
\hline \multicolumn{3}{|l|}{ Inventory Results } & a $-x$ \\
\hline \multicolumn{4}{|c|}{ Bunga Jenis K5 Solution } \\
\hline Parameter & Value & Parameter & Value \\
\hline Demand rate(D) & 273 & Optimal production quantity $\left(Q^{*}\right)$ & 461.04 \\
\hline Setup/Ordering cost(S) & 386666.7 & Maximum Inventory Level (Imax) & 459.76 \\
\hline Holding cost(H) & 996 & Average inventory & 229.88 \\
\hline Daily production rate(p) & 275 & Production runs per period (year) & .59 \\
\hline Days per year (D/d) & 360 & Annual Setup cost & 228962.7 \\
\hline Daly demand rate & .76 & Annual Holding cost & 228962.7 \\
\hline \multirow[t]{3}{*}{ Unit cost } & 105000 & & \\
\hline & & Unit costs $(P D)$ & 28665000 \\
\hline & & Total Cost & 29122930 \\
\hline
\end{tabular}

Gambar 13. Economic Production Quantity Bunga Jenis K5

Gambar 13 Menunjukkan kuantitas pemesanan optimal bunga Jenis K5 sebesar 461 lusin, level persediaan maksimal sebesar 460 lusin, rata-rata persediaan 230 lusin, banyaknya produksi per periode (tahun) sebesar 1 kali. Biaya pemesanan tahunan sebesar Rp.228.963, biaya penyimpanan tahunan sebesar Rp. 228.963. Untuk biaya unit sebesar Rp. 28.665.000 dan Total Biaya sebesar Rp. 29.122.930.

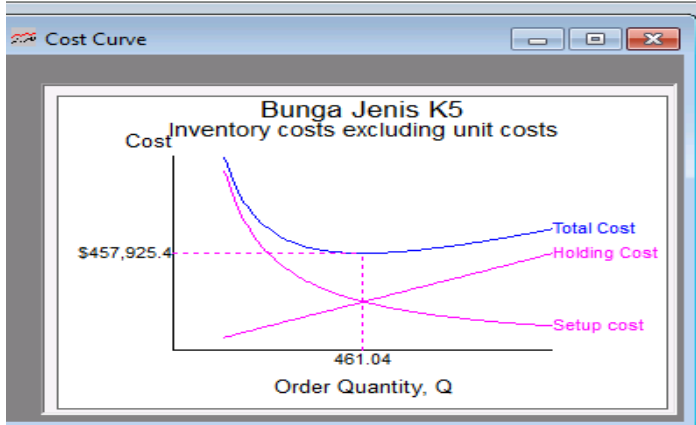

Gambar 14. Kurva persediaan EPQ Bunga Jenis K5

Gambar 14. Menjelaskan bahwa titik persediaan optimal di dapat apabila biaya minimum sebesar Rp.457.925 dan berada pada tingkat persediaan sebesar 461 lusin.

\begin{tabular}{|c|c|c|c|}
\hline \multicolumn{3}{|l|}{ Inventory Results } & $\square \quad \square$ \\
\hline \multicolumn{4}{|c|}{ Bunga Jenis K6 Solution } \\
\hline Parameter & Value & Parameter & Value \\
\hline Demand rate(D) & 312 & Optimal production quantity ( $\left.Q^{*}\right)$ & 492.87 \\
\hline Setup/Ordering $\cos ($ (S) & 386666.7 & Maximum Inventory Level (Imax) & 491.51 \\
\hline Holding $\cos (\mathrm{H})$ & 996 & Average inventory & 245.76 \\
\hline Dally production rate(p) & 315 & Production runs per period (year) & .63 \\
\hline Days per year (D/d) & 360 & Annual Setup cost & 244772.2 \\
\hline Daily demand rate & .87 & Annual Holding cost & 244772.2 \\
\hline \multirow[t]{3}{*}{ Unit cost } & 115000 & & \\
\hline & & Unit costs $(P D)$ & 35880000 \\
\hline & & Total Cost & 36369540 \\
\hline
\end{tabular}

Gambar 15. Economic Production Quantity Bunga Jenis K6

Gambar 15 Menunjukkan kuantitas pemesanan optimal bunga Jenis K6 sebesar 493 lusin, level persediaan maksimal sebesar 492 lusin, rata-rata persediaan 246 lusin, banyaknya produksi per periode sebesar 1 kali. Biaya pemesanan tahunan sebesar Rp.244.772, biaya penyimpanan tahunan sebesar Rp.244.772. Untuk biaya unit sebesar Rp. 35.880.000 dan Total Biaya sebesar Rp.36.369.540.

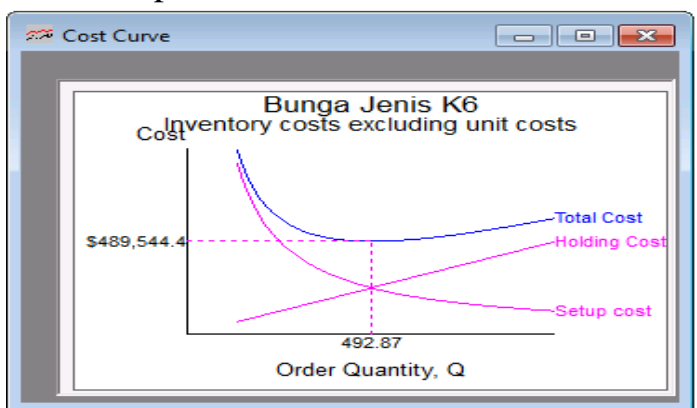

Gambar 16. Kurva Persediaan EPQ Bunga Jenis K6

Gambar 16 Menjelaskan bahwa titik persediaan optimal di dapat apabila biaya minimum sebesar Rp.489.544 dan berada pada tingkat persediaan sebesar 493 lusin.

\begin{tabular}{|c|c|c|c|}
\hline \multicolumn{3}{|l|}{ Inventory Results } & \begin{tabular}{|l|l|} 
& 0 \\
\end{tabular} \\
\hline \multicolumn{4}{|c|}{ Bunga Jenis K10 Solution } \\
\hline Parameter & Value & Parameter & Value \\
\hline Demand rate(D) & 459 & Optimal production quantity $\left(Q^{*}\right)$ & 597.8: \\
\hline Setup/Ordering $\operatorname{cost}(\mathrm{S})$ & 386666.7 & Maximum Inventory Level ( $\max$ ) & 596.16 \\
\hline Holding cost(H) & 996 & Average inventory & 298.08 \\
\hline Dally production rate(p) & 465 & Production runs per period (year) & .77 \\
\hline Days per year (D/d) & 360 & Annual Setup cost & 296888.4 \\
\hline Daily demand rate & 1.28 & Annual Holding cost & 296888.3 \\
\hline \multirow[t]{3}{*}{ Unit cost } & 125000 & & \\
\hline & & Unit costs (PD) & 57375000 \\
\hline & & Total Cost & 57968780 \\
\hline
\end{tabular}

Gambar 17. Economic Production Quantity Bunga Jenis K10 
Gambar 17 Menunjukkan kuantitas pemesanan optimal bunga Jenis K10 sebesar 598 lusin, level persediaan maksimal sebesar 596 lusin, rata-rata persediaan 298 lusin, banyaknya produksi per periode sebesar 1 kali. Biaya pemesanan tahunan sebesar Rp.296.888, biaya penyimpanan tahunan sebesar Rp.296.888. Untuk biaya unit sebesar Rp.57.375.000 dan Total Biaya sebesar Rp.57.968.780.

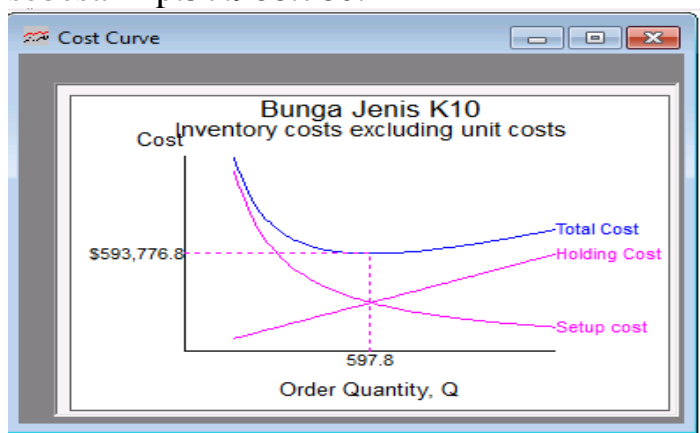

Gambar 18. Kurva persediaan Bunga Jenis K10

Gambar 18 Menjelaskan bahwa titik persediaan optimal di dapat apabila biaya minimum sebesar Rp. 593.777 dan berada pada tingkat persediaan sebesar 598 lusin.

Tabel 7. Perbandingan Total Biaya Persediaan Antara Metode Yang Digunakan Perusahaan, Metode EOQ Dan Metode EPQ

\begin{tabular}{|l|l|l|l|}
\hline $\begin{array}{l}\text { Jenis } \\
\text { Bunga }\end{array}$ & $\begin{array}{l}\text { Biaya } \\
\text { Persediaan } \\
\text { Perusahaan } \\
\text { Rp) }\end{array}$ & $\begin{array}{l}\text { Biaya } \\
\text { Persediaan } \\
\text { Metode } \\
\text { EOQ (Rp) }\end{array}$ & $\begin{array}{l}\text { Biaya } \\
\text { Persediaan } \\
\text { Metode } \\
\text { EPQ (Rp) }\end{array}$ \\
\hline K5 & 39.304 .821 & 29.131 .680 & 29.122 .930 \\
\hline K6 & 46.714 .080 & 36.376 .640 & 36.369 .540 \\
\hline K10 & 63.424 .821 & 57.976 .060 & 57.968 .780 \\
\hline Jumlah & 149.444 .45 & 123.484 .380 & 123.461 .25 \\
0 & & & 0 \\
\hline
\end{tabular}

Tabel 7 menjelaskan bahwa biaya yang di keluarkan oleh perusahaan untuk periode tahun 2016 adalah sebesar Rp. 149.444.450. Dengan Menggunakan Metode EOQ total biaya yang dikeluarkan periode tahun 2016 adalah Rp.123.484.380.
Sedangkan menurut metode EPQ yaitu Rp.123.461.250.

\section{KESIMPULAN}

1. Dari perhitungan data yang ada dapat dilihat bahwa jumlah pemesanan ekonomis menggunakan metode EOQ untuk bahan baku bunga krans jenis K5, K6 dan K10 yaitu masing-masing 460 lusin, 492 lusin dan 597 lusin. Dan jumlah produksi optimal dengan metode EPQ untuk bahan baku bunga krans jenis K5, K6 dan K10 yaitu masingmasing 461 lusin, 493 lusin dan 598 lusin.

2. Total biaya persediaan minimum menurut metode EOQ untuk bunga jenis K5 adalah Rp. 29.131.680, Jenis K6 adalah Rp. 36.376.640 dan Jenis K10 adalah Rp. 57.976.060. Dengan jumlah total biaya yang dikeluarkan menurut metode EOQ yaitu sebesar Rp. 123.484.380. Total biaya persediaan minimum menurut metode EPQ untuk bunga jenis K5 adalah Rp. 29.122.930, Jenis K6 adalah Rp. 36.369 .540 dan jenis K10 adalah Rp. 57.968.780. Dengan jumlah total biaya yang dikeluarkan menurut metode EPQ adalah sebesar Rp. 123.461.250.

3. Titik pemesanan kembali terjadi apabila persediaan bunga plastik digudang untuk bunga jenis K5 sebanyak 9 lusin, bunga jenis K6 sebanyak 7 lusin dan bunga jenis K10 sebanyak 8 lusin.

4. Berdasarkan perhitungan yang didapat dapat dilihat bahwa metode EOQ dan metode EPQ dapat mengurangi biaya persediaan dibandingkan dengan kebijakan perusahaan. Dimana metode EOQ dapat menghemat biaya sebesar Rp. 25.960.070. Sedangkan metode EPQ dapat menghemat biaya sebesar Rp. 25.983.200. Namun jika dibandingkan metode EOQ dan EPQ dapat dilihat bahwa metode EPQ dapat meminimalkan biaya dibandingkan dengan metode EOQ dengan selisih sebesar Rp. 23.130 . 


\section{DAFTAR PUSTAKA}

Kamus Besar Bahasa Indonesia. 2012. Krans . http://kbbi.web.id/krans . [20 Februari 2017]

Limansyah,T.,D.Lasmono.2011. Model Persediaan Multi Item Dengan Mempertimbangkan Faktor Kadaluarsa dan Faktor All Unit Discount. Jurnal Teknik Industri.13(2):87-94.

Asrori,H. 2010.Analisis Pengendalian Persediaan Bahan Baku Kayu Sengon PT. Abhirama Kresna Dengan Metode EOQ [skripsi]. Fakultas Ekonomi Universitas Sebelas Maret Surakarta, Surakarta.

Simbar, M., T.M Katiandagho., T.F Lolowang., dan J. Baroleh. 2014. Analisis Pengendalian Persediaan Bahan Baku Kayu Cempaka Pada Industri Mebel Dengan Menggunakan Metode EOQ (Studi Kasus Pada UD.Batu Zaman. Jurnal Ilmiah. 5(3):1-15.

Sibarani, E., F. Bu'ulolo, D. Sebayang. 2013. Penggunaan Metode EOQ Dan EPQ Dalam Meminimumkan Biaya Persediaan Minyak Sawit Mentah (CPO). Saintia Matematika. 337-347.

Fahmi,I. 2012. Manajemen Produksi Dan Operasi. Alfabeta; Bandung

Taha, H.A.1982, Operation Research an Introduction. MacMillan Publishing Co, Inc, New York.

Taha, H.A. 2007, Operation Research, 8th ed., Pearson Prentice Hall, New Jersey.

Yamit., Zhulian. 2002. Manajemen Persediaan. Ekonisia Fakultas Ekonomi UI, Yogyakarta . 